\title{
In Vitro Efficacy of Bacterial Endophytes against Pythium sp. Causing Soft Rot of Ginger in Meghalaya
}

\author{
Meshanki Bamon*, Dipali Majumder, Dwipendra Thakuria and Thangaswami Rajesh
}

Department of Plant Pathology, College of Post-Graduate Studies, Central Agricultural University (Imphal), Umiam-793103, Meghalaya, India

*Corresponding author

\begin{tabular}{|l|}
\hline Ke y w or d s \\
$\begin{array}{l}\text { Bacterial endophytes, } \\
\text { Pythium, Ginger, } \\
\text { Bacillus, Meghalaya }\end{array}$ \\
\hline Article Info \\
\hline $\begin{array}{l}\text { Accepted: } \\
\text { 04 July } 2018 \\
\text { Available Online: } \\
\text { 10 August } 2018\end{array}$ \\
\hline
\end{tabular}

\section{A B S T R A C T}

The present study was conducted to evaluate bacterial endophytes against Pythium spp. causing soft rot of ginger. Water soaked lesions at the emerging base and the collar region was the typical symptoms observed on infected plants. Sprout appeared pale yellowish and withering off of plant was seen and such rhizomes were rotten and emitted foul smell in which diseased plants came off with a gentle pull. Six potential bacterial endophytes viz., Alcaligenes sp. (GE-1), Bacillus cereus (GE-2), Bacillus sp. (GE-3), Bacillus sp. (GE-4), Bacillus sp. (GE-5), Bacillus thuringiensis (GE-6) were evaluated by dual culture assay and endophytes were successful in inhibiting the mycelial growth of the Pythium sp. causing soft rot of ginger. Of which, Alcaligenes sp. (GE-1) showed highest per cent inhibition of $80.98 \%$ followed by Bacillus sp. (GE-4) and Bacillus sp. (GE-5) of $78.89 \%$ and $77.33 \%$ inhibition respectively. The least inhibition was observed in Bacillus sp. (GE3 ) with $64.89 \%$. In vitro evaluation found that four isolates were highly effective as it gave more than $70 \%$ inhibition in growth of Pythium spp. Therefore these isolates can be used in consortia mode in field condition against ginger soft rot.

\section{Introduction}

Ginger (Zingiber officinale Rosc.) is a herbaceous, rhizomatous, flowering perennial plant belonging to the family Zingiberaceae. It is used as a spice, food, flavouring agent, and medicine. The spice has a slightly biting taste and is used to flavour breads, sauces, curry dishes, confections and pickles. India is known as the "The Land of Spices" and the glory of Indian spices is known throughout the world. India is the largest producer of ginger accounting for about $1 / 3^{\text {rd }}$ of total world output (Ravishanker et al., 2014). In India, ginger is cultivated in an area of 1,65,000 ha with the production of $10,81,000$ tonnes/ha during 2016-17. In North East (NE) India, Assam ranked first with a production of 16,65,000 tonnes/ha and Meghalaya stand second in the production $(6,64,000$ tonnes/ha) of ginger (Anonymous, 2017).

In India, a large portion of the ginger produced is consumed domestically as green ginger or dried ginger. It is cultivated in many states, but major producers are viz., Karnataka, Kerala, Assam, Meghalaya, Arunachal Pradesh, Orissa, West Bengal and Mizoram. 
Spices including ginger are affected by many constraints such as improper seed selection, insects, nematodes and diseases that can significantly reduce yield and quality of crop. Among the major constraints of ginger production, rhizome rot disease is very important in view of severe crop losses. This disease is mainly caused by the Pythium spp. (P. aphanidermatum, $P$. myriotylum, $P$. vexans, $P$. ultimum, $P$. deliense and $P$. pleroticum) (Sarma, 1994). It occurs more serious in several parts of India wherever the crop is grown including Meghalaya. Heavy yield loss due to the disease has been reported in Meghalaya ranging from 57 to $100 \%$ in West Garo Hills and 57\% in Ri Bhoi district (Dohroo et al., 2012). Though fungicides control damping-off, but they are not a long term solution due to concerns over exposure, health and environmental hazards and residue persistence. The resistance of microorganisms against antimicrobial drugs is a major problem of recent times, which is increasing day by day (Cohen, 2000; Kumar et al., 2013).

As a result, in recent years the approach has been shift to control diseases using endophytic bacteria and other bio-control agents which are safe and promising alternative to synthetic pesticides. There have been evidences that endophytes contribute to control of plant diseases (Kloepper et al., 1992).

Bacterial endophytes can confer resistance or tolerance to the host plant from biotic and abiotic stresses by releasing antimicrobial compounds, producing siderophores, competing for space and nutrients, and modulating the plant resistance response Bacterial endophytes such as Bacillus sp and Pseudomonas sp was exploited as potential bio control agent in controlling plant diseases, therefore the present investigation was carried out to evaluate the efficacy of bacterial endophytes in managing rhizome rot of ginger caused by Pythium spp. in vitro.

\section{Materials and Methods}

\section{Collection and isolation of pathogen}

Infected rhizome of ginger showing water soaked lesion were collected from farmers' field of Ri-Bhoi district in Meghalaya. Infected rhizomes and were then brought to laboratory and washed with tap water to remove soil sample and infected portion were then observed microscopically. After confirming for the presence of fungal spores, isolation was done by tissue segment method (Rangaswami, 1958). Rhizomes showing characteristic of water soaked symptom were cut into small pieces of $2 \mathrm{~mm}$ along with some healthy portions. The pieces were then surface sterilized in 0.1 per cent mercuric chloride solution for 20-30 sec, followed by serial washing in sterile distilled water for three times. Six to seven pieces of infected rhizomes bits $(5 \mathrm{~mm})$ were blot dried on sterile filter paper and placed on corn meal agar (CMA) for isolation of Pythium sp. Upon two days of incubation at $27 \pm 1^{\circ} \mathrm{C}$, a hyphal tip growing from infected bits were transferred to water agar (WA) and was incubated for two days at $27 \pm 1^{\circ} \mathrm{C}$ in dark condition. The growing hyphal tips in WA were then further transferred to PDA plates and were incubated at $27 \pm 1^{\circ} \mathrm{C}$. The pure culture of the fungus was then transferred to CMA slants. Such culture tubes were preserved in a refrigerator at $4^{\circ} \mathrm{C}$ for further studies.

\section{Collection of bacterial endophytes}

Six potential bacterial endophytes viz., Alcaligenes sp. (GE-1), Bacillus cereus (GE2), Bacillus sp. (GE-3), Bacillus sp. (GE-4), Bacillus sp. (GE-5), Bacillus thuringiensis (GE-6), screened against Pythium myriotylum were used in the study. These bacterial endophytes were isolated from different ginger species from different states of North Eastern Hill $(\mathrm{NEH})$ region of India and were 
collected from Plant Pathology lab, School of Crop Protection, College of Post-Graduate Studies, Central Agricultural University (Imphal), Umiam, Meghalaya.

\section{Maintenance of bacterial endophytes}

The pure cultures of the bacterial isolates were maintained by regular sub-culturing every two months in nutrient agar (NA) slants and stored at $4{ }^{\circ} \mathrm{C}$ in refrigerator. The isolates will also be preserved in Luria-Bertani (LB) broth containing $30 \%$ glycerol $(\mathrm{v} / \mathrm{v})$ and maintained at $-20{ }^{\circ} \mathrm{C}$ and in mineral oil at $-20^{\circ} \mathrm{C}$.

\section{Efficacy of bacterial endophytes against Pythium spp.}

The bacterial antagonist was evaluated by inoculating a $5 \mathrm{~mm}$ mycelial disc of associated pathogen at the centre of the petri plates and bacterial antagonist was streaked at two sides of the seeded disc of pathogen maintaining 2 $\mathrm{cm}$ gap in between. For this experiment, actively growing cultures were used. Each treatment was replicated three times and was incubated at $27 \pm 1^{0} \mathrm{C}$ for four- six days. After control plates reached $9 \mathrm{~cm}$ diameter or less, the radial growth of pathogen was measured. Percent inhibition over control was worked out according to the equation given by Berg et al., (2002) as follows:

$\mathrm{I}=(\mathrm{C}-\mathrm{T} / \mathrm{T}) \mathrm{X} 100$

Where,

$\mathrm{I}=$ Per cent inhibition of mycelial growth,

$\mathrm{C}=$ Growth in control and

$\mathrm{T}=$ Growth in treatment

\section{Statistical Analysis}

The above mentioned in vitro experiment was conducted by using the statistical completely randomized block design (CRD) wherever applicable. Three replications were maintained in experiments required. All data obtained in the present investigation were statistically analysed by one-way analysis of variance (ANOVA). The significant difference if any, among the treatments were compared by using critical difference $(C D)$ at $\mathrm{p}=0.05$ significance level.

\section{Results and Discussion}

\section{Collection and isolation of pathogen}

The diseased sample was collected from farmer's field at Umsning village, Ri-bhoi district, Meghalaya. Ginger plants along with rhizomes were examined before collection for symptomatological studies since each associated pathogen is responsible for its typical symptom expression.

In soft rot infected crop foliar yellowing was clearly observed, which started from the tip and extended along the margins of the lower most leaves.

Water soaked lesions at the emerging base and the collar region was observed in the soft rot infected plants. The whole sprout appeared pale yellowish and withering off of plant was seen. Such rhizomes were rotten and emitted foul smell. Diseased plants came off with a gentle pull. In a mature plant, foliar yellowing and stunted growth of the plants were observed.

\section{Efficacy of bacterial endophytes against Pythium spp.}

AlI the six potential bacterial endophytes viz., Alcaligenes sp. (GE-1), Bacillus cereus (GE2), Bacillus sp. (GE-3), Bacillus sp. (GE-4), Bacillus sp. (GE-5), Bacillus thuringiensis (GE-6) after tested were successful in inhibiting the mycelial growth of the Pythium $s p$. causing soft rot of ginger. 
Fig.1 Bar diagram showing the radial growth of Pythium sp. against various bacterial endophytes

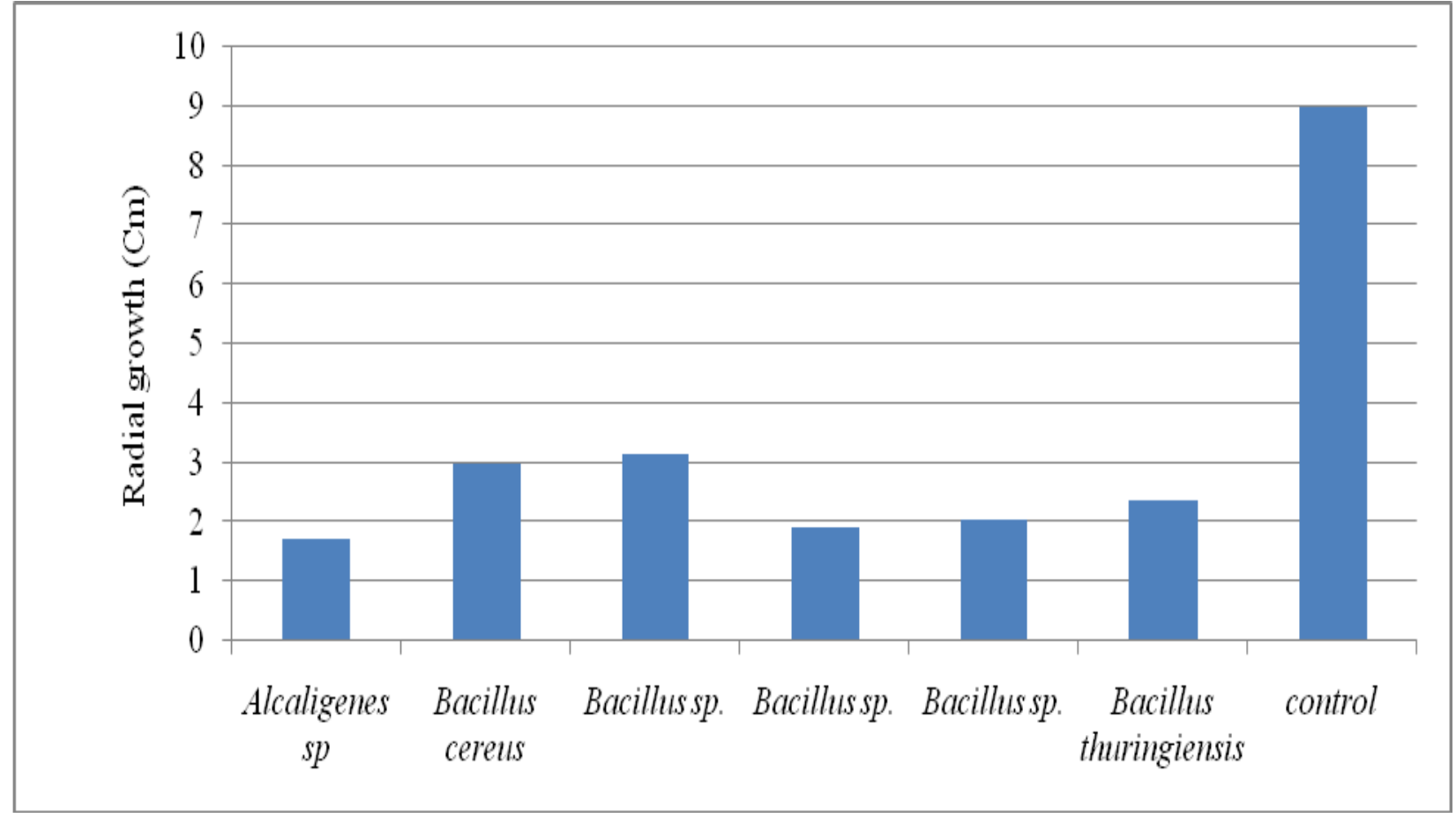

Fig.2 Bar diagram showing the per cent inhibition of bacterial endophytes against Pythium sp. in vitro

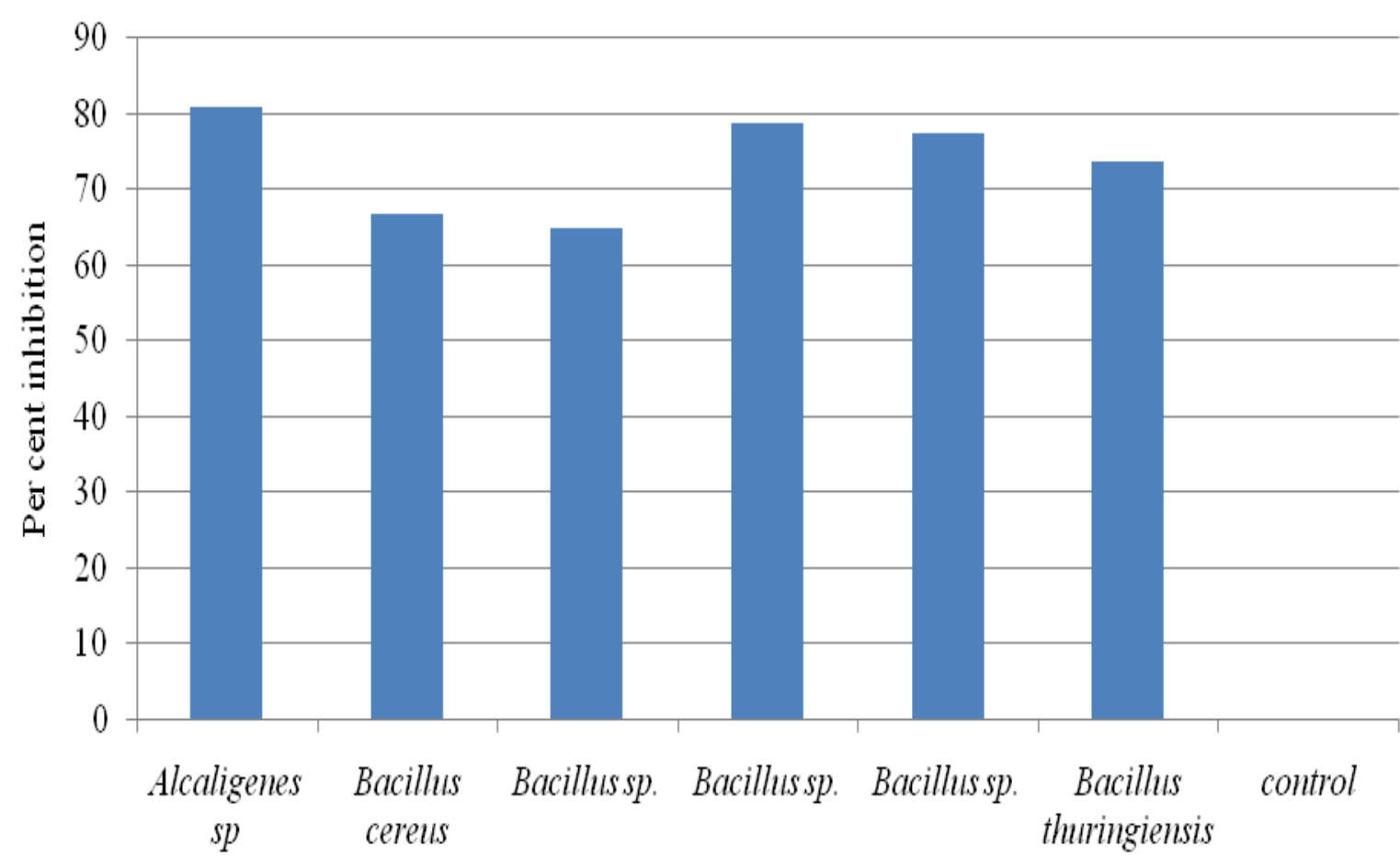


Table.1 Efficacy of bacterial endophytes against Pythium spp.

\begin{tabular}{|c|c|c|c|}
\hline \multicolumn{2}{|l|}{ Treatments } & Radial growth $(\mathrm{Cm}) *$ & $\begin{array}{l}\text { Per cent inhibition } \\
\text { over control }\end{array}$ \\
\hline Alcaligenes sp & GE-1 & $\begin{array}{c}1.90 \pm 0.03^{\mathrm{f}} \\
(1.38)\end{array}$ & $\begin{array}{c}80.98 \pm 0.22^{b} \\
(64.15)\end{array}$ \\
\hline Bacillus cereus & GE-2 & $\begin{array}{c}2.36 \pm 0.03^{d} \\
(1.54)\end{array}$ & $\begin{array}{c}66.85 \pm 0.49^{d} \\
(54.85)\end{array}$ \\
\hline Bacillus sp. & GE-3 & $\begin{array}{c}2.04 \pm 0.05^{\mathrm{e}} \\
\quad(1.43)\end{array}$ & $\begin{array}{c}64.89 \pm 0.34^{c} \\
\quad(53.66)\end{array}$ \\
\hline Bacillus sp. & GE-4 & $\begin{array}{c}1.71 \pm 0.02^{\mathrm{g}} \\
(1.31)\end{array}$ & $\begin{array}{c}78.89 \pm 0.32^{a} \\
(62.65)\end{array}$ \\
\hline Bacillus sp. & GE-5 & $\begin{array}{c}2.98 \pm 0.04^{\mathrm{c}} \\
(1.73)\end{array}$ & $\begin{array}{c}77.33 \pm 0.51^{\mathrm{e}} \\
(61.57)\end{array}$ \\
\hline Bacillus thuringiensis & GE-6 & $\begin{array}{c}3.16 \pm 0.03^{b} \\
(1.78)\end{array}$ & $\begin{array}{c}73.78 \pm 0.34^{\mathrm{f}} \\
(59.20)\end{array}$ \\
\hline \multicolumn{2}{|l|}{ control } & $\begin{array}{c}9.00 \pm 0.00^{\mathrm{a}} \\
(3.00)\end{array}$ & $\begin{array}{c}0.00 \pm 0.00^{\mathrm{g}} \\
(0.63)\end{array}$ \\
\hline \multicolumn{2}{|l|}{$\mathbf{S E}(\mathbf{m})$} & 0.002 & 0.002 \\
\hline \multicolumn{2}{|c|}{$\mathrm{CD}(\mathrm{p}=\mathbf{0 . 0 5})$} & 0.032 & 0.704 \\
\hline $\begin{array}{l}\text { * Mean of three replicat } \\
\text { Note: Data in parenthes } \\
\text { transformation over con } \\
\text { GE: Ginger Endophyte }\end{array}$ & D & $\begin{array}{l}\text { transform fo } \\
\text { nhibition }\end{array}$ & ine \\
\hline
\end{tabular}

Plate.1 (a) Pythium infected ginger rhizome; (b) Microscopic view of Pythium spores; (c) Front view of mycelial growth on PDA media; (d) Back view of mycelial growth on PDA media

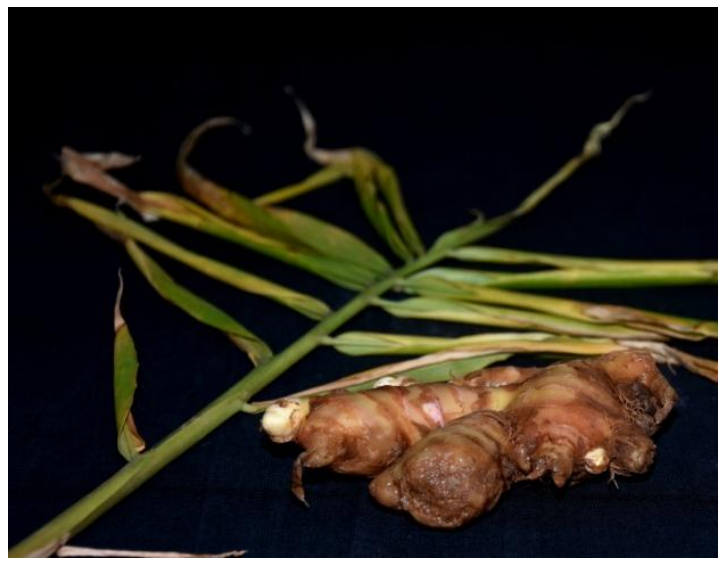

(a)

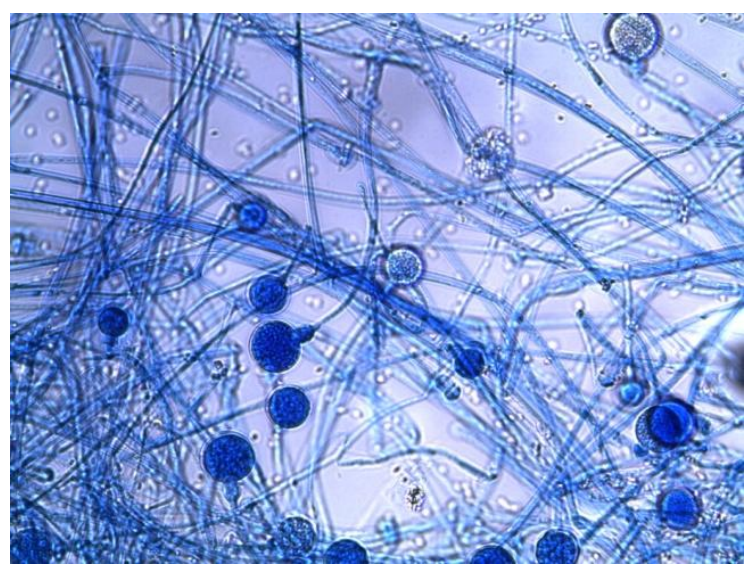

(b) 


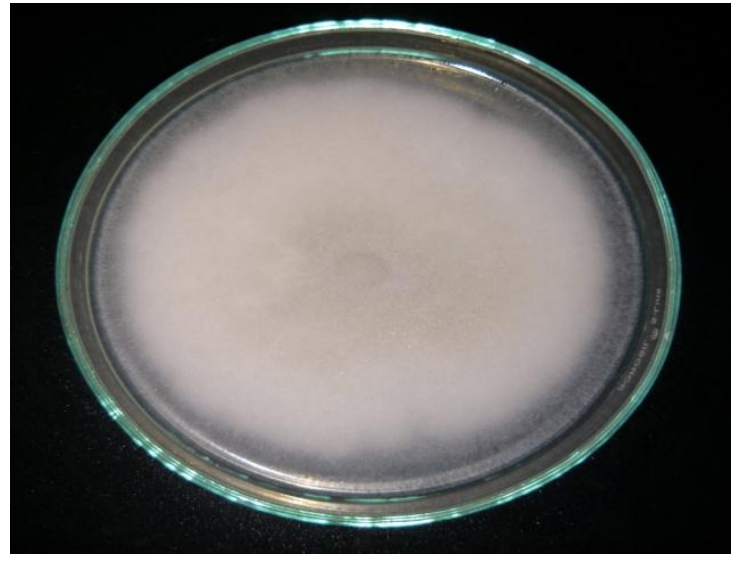

(c)

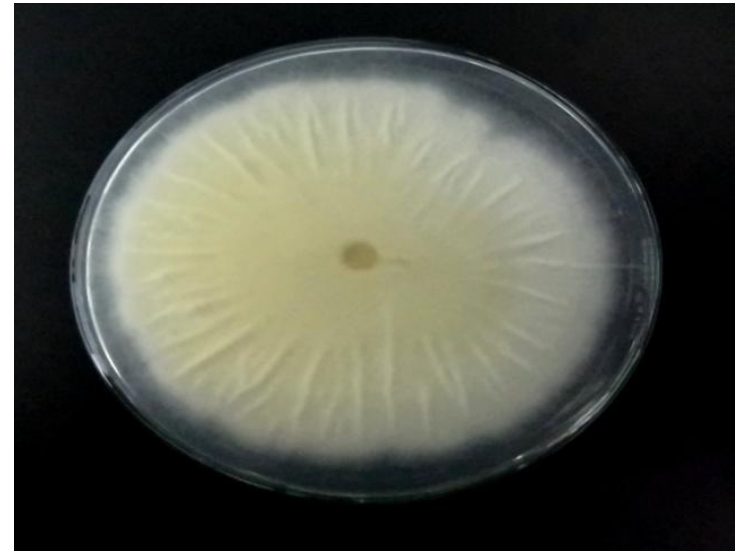

(d)

Plate.2 Efficacy of bacterial endophytes against Pythium spp.

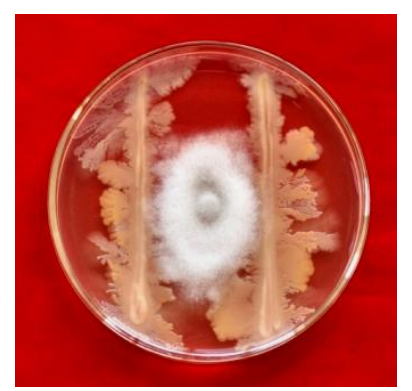

Alcaligenes sp (GE-1)

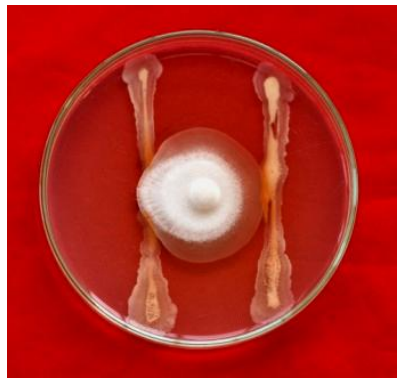

Bacillus sp. (GE-4)

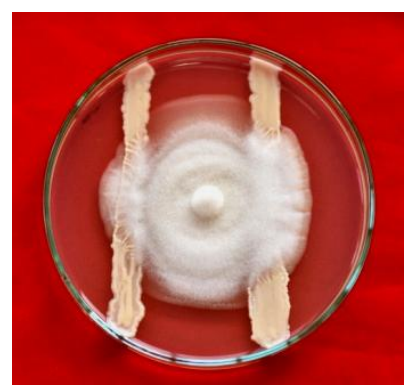

Bacillus cereus (GE-2)

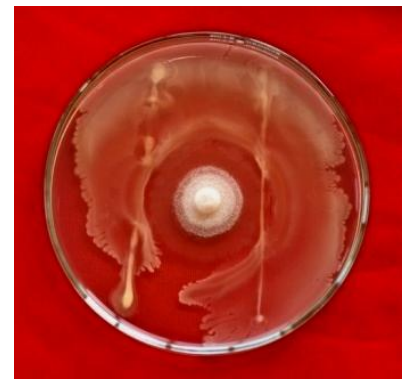

Bacillus sp. (GE-5)

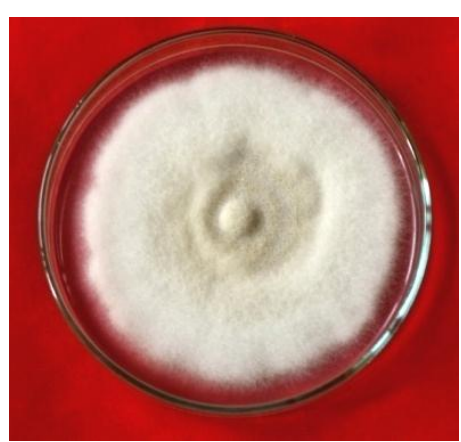

Control

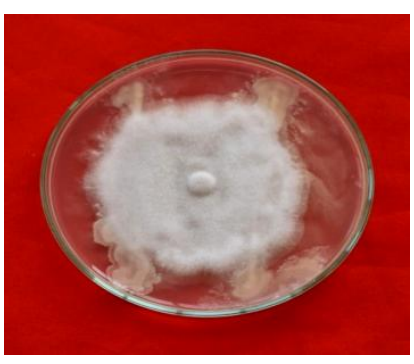

Bacillus sp. (GE-3)

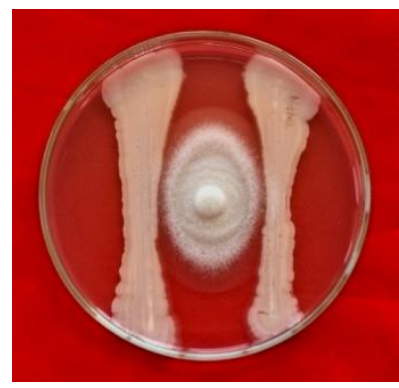

Bacillus thuringiensis (GE-6) 
Of which, Alcaligenes sp. (GE-1) showed highest per cent inhibition of $80.98 \%$ followed by Bacillus sp. (GE-4) and Bacillus sp. (GE-5) of $78.89 \%$ and $77.33 \%$ inhibition respectively. The least inhibition was observed in Bacillus sp. (GE-3) with $64.89 \%$ (Table 1; Plate 2).

The present study found that there was water soaked lesions at the collar region in the soft rot infected plants. Similarly Dohroo (2005) reported that rhizomes from diseased plants appear brown, water soaked, soft and rotten, and will decay gradually.

The antagonistic effects of the bacterial endophytes against the Pythium spp were checked by dual culture method. Among the six bacterial endophytes evaluated against Pythium spp, best endophyte was Alcaligenes sp. (GE-1) as it showed highest per cent inhibition of $80.98 \%$ followed by Bacillus sp. (GE-4) and Bacillus sp. (GE-5) of $78.89 \%$ and $77.33 \%$ inhibition respectively and the least inhibition was observed in Bacillus sp. (GE-3) with $64.89 \%$.

The ability of the bacterial endophytes to suppress the growth of the pathogen maybe reflected to their ability to produced hydrolytic enzyme responsible for the degradation of the pathogen cell wall. The present findings is supported by Dinesh et al., (2015) who reported that isolate Bacillus GRB35 amyloliquefaciens exhibited $78.51 \%$ inhibition in growth of $P$. myriotylum in ginger.

Endophytic bacteria could serve as potential antagonist to prevent the infection of plant pathogenic organisms. In vitro evaluation of six bacterial endophytes revealed that four isolates were highly effective as it gave more than $70 \%$ inhibition in growth of Pythium spp. Therefore these isolates could be used in consortia mode in field condition and if successful, effective bioformulation can be developed by using potential endophytes.

\section{References}

Anonymous. 2017. Horticulture statistics at a glance. Indian Horticulture Database.

Berg, G., N, Roskot, A, Steidle, L, Eberl, A. Zock, and Smalla, K. 2002. Plantdependent genotypic and phenotypic diversity of antagonistic rhizobacteria isolated from different Verticillium host plants. Appl. Environ. Microbial. 68(7): 3328-3338.

Cohen, M.L., 2000. Changing patterns of infectious disease. Nature, 406(6797): 762-767.

Dhoroo, N.P., S. Kansal, and Ahluwalia, N. 2012. Status of soft rot of ginger (Zingiber officinale Rosc.). Department of vegetable science, Dr. Y.S. Parmer University of Horticulture and Forestry, Nauni, Solan-173230. Himachal Padesh.

Dinesh, R., M, Anandaraj, A, Kumar, Y.K, Bini, K.P, Subila, and Aravind, R. 2015. Isolation, characterization, and evaluation of multi-trait plant growth promoting rhizobacteria for their growth promoting and disease suppressing effects on ginger. Microbiol. Res., 173: 34-43.

Dixon, R.A., 2001. Natural products and plant disease resistance. Nature. 411: 843847. Kloepper, J.W., B. Schippers and Bakker, P.A.H.M. 1992. Proposed elimination of the term endorhizosphere. Phytopathol., 82: 726727.

Dohroo, N.P. 2005. Diseases of ginger. In: Ginger, the Genus Zingiber (Ravindran, P.N. and Babu, K.N., (Eds.), CRC Press, Boca Raton, pp. 305-340.

Friesen, M.L., S.S. Porter, S.C. Stark, Von Wettberg, E.J. and Sachs, J.L. 2011. Microbially Mediated Plant Functional 
Traits. Annu. Rev. Ecol. Evol. Syst., 42, 23-46.

Mercado-Blanco, J., and Lugtenberg, B. 2014.

Biotechnological Applications of

Bacterial Endophytes. Curr.

Biotechnol., 3:60-75.

Rangaswami, G., 1958. An agar blocks technique for isolating soil microorganisms with special reference to Pythiaceous fungi. Sci. and Cult. 24: 85.
Ravishanker, S. Kumar, A. Chatterjee, D. K. Baranwal, and Solankey, S.S. 2014. Genetic variability for yield and quality traits in ginger (Zingiber officinale Roscoe). The Bioscan. 8(4): 1383-1386. Santoyo, G., G. Moreno-Hagelsieb, M. Del Carmen Orozco-Mosqueda, and Glick, B.R. Plant growth-promoting bacterial endophytes. Microbiol. Res. 2016, 183: 92-99.

\section{How to cite this article:}

Meshanki Bamon, Dipali Majumder, Dwipendra Thakuria and Thangaswami Rajesh. 2018. In Vitro Efficacy of Bacterial Endophytes against Pythium sp. Causing Soft Rot of Ginger in Meghalaya. Int.J.Curr.Microbiol.App.Sci. 7(08): 367-374.

doi: https://doi.org/10.20546/ijcmas.2018.708.041 